\title{
Ação Social / Social Action
}

https://doi.org/10.21814/uminho.ed.36.1

\section{Daniel Stoecklin}

Université de Genève, Switzerland 



\section{Ação Social}

A ação social pode ser descrita como a ação de fazer algo de forma influenciada pela sociedade.

Uma ação é social na medida em que é dirigida por um self reflexivo que é capaz de sentir como os outros podem avaliar essa ação. Comecemos com um exemplo simples do que pode ser considerado uma ação natural e social: respirar. Respirar é um processo natural e, principalmente, inconsciente. No entanto, pode tornar-se uma ação social quando é objeto da atenção de outros (por exemplo, um médico, um grupo de praticantes de ioga) ou quando é restringido por outros (durante uma reunião stressante, uma competição desportiva, etc.). Em tais situações, o ator está a fazer algo (respirar) num ambiente social onde as regras de interação humana e as lógicas de associação prevalecem. Então, o comportamento do ator segue inconscientemente essas regras e lógicas ou decorre do modo "como ele interpreta e lida com essas coisas na ação que está a construir"? (Blumer, 1979, p. 21). Também pode haver uma mistura entre influências conscientes e inconscientes. Este exemplo mostra que é principalmente o estatuto atribuído à reflexividade do ator que está em jogo nas teorias sociológicas da ação.

Dois caminhos foram percorridos: o paradigma determinista e o paradigma interpretativo.

O primeiro, traçado por Émile Durkheim, considera a sociedade como uma realidade substancial. Assim, a ação social compreende "modos de agir, pensar e sentir, externos ao indivíduo, que são investidos de um poder coercivo em virtude do qual exercem o controlo sobre ele" (Durkheim, 1982, p. 52). A segunda, traçada por Max Weber, vê a sociedade como resultado de reconstruções intersubjetivas. Assim, as interpretações dos atores são centrais: "Falaremos de ação [Handeln] na medida em que o indivíduo atuante atribui um significado subjetivo ao seu comportamento - seja ele aberto ou encoberto, por omissão ou aquiescência. A ação é social na medida em que o seu significado subjetivo [gemeinten Sinn] leva em conta o comportamento dos outros e, portanto, é orientado no seu curso" (Weber, 1968, p. 4). Com tal diferença de ênfase colocada na construção contínua de significado no decurso da interação, pode ser tentador classificar os dois paradigmas 
numa dicotomia entre subjetivismo e objetivismo e entre ação coletiva e individual. Ainda, o paradigma interpretativo vincula o significado subjetivo dado aos comportamentos dos outros a uma perspetiva coletiva e objetiva, ou seja, a antecipação dos tipos de motivos que deveriam orientar comportamentos em determinadas situações (Ogien \& Quéré, 2005, pp. 6-7). Esses motivos compartilhados coletivamente constroem a tipologia de ações sociais de Weber: instrumental-racional, quando realizada como meio para atingir com eficiência um determinado objetivo; valor-racional, quando determinado por uma crença no seu valor inerente; afetiva, quando impulsivamente se apoia nas emoções; tradicional, quando controlada por costumes inquestionáveis.

Consequentemente, as construções individuais de significado não podem ser separadas dos motivos dominantes que orientam as ações sociais. Além disso, embora uma ação social seja mais ou menos intencional, também pode ter consequências não intencionais (Boudon). Essas repercussões acontecem porque a associação humana é dirigida por lógicas que não podem ser controladas pelos atores. Se as escolhas e oportunidades são limitadas por uma "estrutura" social definida em termos de "arranjos padronizados recorrentes" da qual dificilmente se está ciente, então "a capacidade dos indivíduos agirem independentemente e fazerem as suas próprias escolhas livres" (Barker, 2005, p. 448) é uma ilusão.

As principais teorias sociológicas de meados do século $X X$, como a teoria funcionalista (Parsons), a teoria da ação coletiva (Olson, Touraine), a teoria dos campos e habitus (Bourdieu), colocam ênfase nesse determinismo social. Na década de 1980, desenvolvimentos importantes sobre agência dentro da estrutura foram feitos. Alguns teóricos consideram a estrutura como meio e resultado da ação social, daí a "dualidade da estrutura" (Giddens), enquanto outros insistem nas dimensões temporais e relacionais da ação social que é condicionada, mas não determinada, pela estrutura e consciência (Bashkar, Arqueiro). Mais recentemente, alguns autores passaram a incluir objetos como "atuantes" (Latour) possuindo algum tipo de agência. Esta nova perspetiva questiona a condição de intencionalidade na ação social e exige que esclareçamos o estatuto dos objetos, pois os objetos concretos e abstratos (ou seja, direitos, convenções) exercem influências de diferentes tipos.

Estes desenvolvimentos destacam de novas maneiras a noção bourdieusiana de habitus como um sistema de disposições inconscientes e duradouras. $\mathrm{O}$ debate sobre os aspetos conscientes e inconscientes da ação social, 
começando com Durkheim e Weber, está, portanto, longe de se esgotar. É especialmente agudo na sociologia da infância, à medida que as capacidades das crianças, em evolução, abrangem a ação inconsciente e consciente em toda a sua amplitude. Isso tem sido questionado particularmente no estudo das brincadeiras e jogos infantis, influenciados pelo paradigma da reprodução interpretativa (Corsaro, 1997).

\section{Social Action}

Social action can be defined as doing something in ways that are influenced by society. An action is social as far it is directed by a reflexive and aware self that is able to sense how others might evaluate this action. Let us start with a simple example of what can be considered as both a natural and social action: breathing. Breathing is a natural and mostly unconscious process. However, it can become a social action when it is the object of attention by others (e.g., a doctor, a group of yoga practitioners) or when constrained and influenced by others (during a stressful meeting, a sport competition, etc.). In such situations, the actor is doing something (breathing) in a social setting where the rules of human interaction and the logics of association prevail. The question is then whether the actor's behaviour is unconsciously following these rules and logics, or whether it is arising from "how he interprets and handles these things in the action which he is constructing"? (Blumer, 1979, p. 21)? There might also be a combination between conscious and unconscious influences. This example shows that it is mainly the status given to the reflexivity of the actor that is at stake in the sociological theories of action.

Two main routes have been paved: the deterministic paradigm and the interpretative paradigm. The first, traced by Emile Durkheim, regards society as a substantial reality. Hence, social action comprises "manners of acting, thinking, and feeling, external to the individual, which are invested with a coercive power by virtue of which they exercise control over him" (Durkheim, 1982, p. 52). The second, traced by Max Weber, sees society as resulting from intersubjective reconstructions. Thus, the actors' interpretations are central: "We shall speak of action [Handeln] insofar as the acting individual attaches a subjective meaning to his behavior - be it overt or covert, omission or acquiescence. Action is social insofar as its subjective meaning [gemeinten Sinn] takes account of the behavior of others and is thereby oriented in its course" (Weber, 1968, p. 4). With such a difference of emphasis placed on the continuous meaning-making in the course of interaction, it can be tempting 
to subsume the two paradigms under a dichotomy between subjectivism and objectivism and a dichotomy between collective and individual action. Yet, the interpretative paradigm links the subjective meaning given to the behaviors of others to a collective and objective perspective, namely the anticipation of the kinds of motives that are supposed to orient behaviors in given situations (Ogien \& Quéré, 2005, pp. 6-7). These collectively shared motives build up Weber's typology of social actions: instrumental-rational, when carried out as means to efficiently reach a certain goal; value-rational, when determined by a belief in their inherent value; affective, when impulsively based on emotions; traditional, when controlled by unquestioned customs.

Consequently, the individual constructions of meaning cannot be divorced from dominant motives orienting social actions. Besides, while a social action is more or less intentional, it can also have unintended consequences (Boudon). These repercussions happen because human association is directed by logics that cannot be controlled by the actors. If choices and opportunities are limited by a social "structure" defined in terms of "recurrent patterned arrangements" one is hardly aware of, then "the capacity of individuals to act independently and make their own free choices" (Barker, 2005, p. 448) is an illusion. Major sociological theories from the middle of the 20th century, such as the functionalist theory (Parsons), the theory of collective action (Olson, Touraine), the theory of fields and habitus (Bourdieu), place emphasis on such social determinism. In the 1980s, important developments in agency within structure were made. Some theorists considered structure as both the medium and outcome of social action, hence the "duality of structure" (Giddens), while others insist on the temporal and relational dimensions of social action that is conditioned but not determined by structure and consciousness (Bashkar, Archer). More recently, some authors began to include objects as "actants" (Latour) having some kind of agency. This new perspective questions the condition of intentionality in social action and requires us to clarify the status of objects, as concrete and abstract objects (i.e., rights, conventions) exert influence of different kinds. These developments highlight in new ways the Bourdieusian notion of habitus as a system of unconscious and lasting actions or behaviour. The debate on the conscious and unconscious aspects of social action, starting with Durkheim and Weber, is therefore far from being exhausted. It is especially relevant in the sociology of childhood, as children's evolving capacities embrace the span of unconscious and conscious acting in the fullest range. This has been raised in particular in the study of children's 
play and games, enlightened by the paradigm of interpretive reproduction (Corsaro, 1997).

\section{Referências / References}

Corsaro, W. (1997). The sociology of childhood. Pine Forge Press: Thousand Oaks.

Durkheim, E. (1985 [1982]). The Rules of Sociological Method (translated by W.D. Halls). New York: The Free Press.

Weber, M. (1919 [1968]). Economy and society: an outline of interpretive sociology (adapted by G. Roth \& C. Wittich). New York: Bedminster Press. 